\title{
Hemicrania persistente como manifestação inicial da síndrome de Ramsay Hunt
}

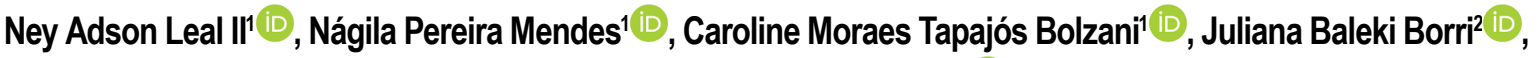 \\ Hilton Mariano da Silva Junior ${ }^{1,2}$ (D)
}

'Hospital Municipal de Campinas Doutor Mário Gatti, Campinas São Paulo, Brasil

2Pontifícia Universidade Católica de Campinas, Campinas, São Paulo, Brasil

\section{Introdução}

A síndrome de Ramsay-Hunt também chamada de zoster otico é uma complicação rara do herpes-zóster em que ocorre reativação de uma infecção latente pelo vírus varicela-zóster no gânglio geniculado. A síndrome é caracterizada por paralisia do nervo facial periférico acompanhada por uma erupção vesicular eritematosa na orelha ou na boca. É a segunda causa mais comum de paralisia facial periférica não traumática.

\section{Objetivos}

Apresentar um caso atípico da síndrome de Ramsay Hunt com presença de cefaleia.

\section{Material e Métodos}

Relato de uma mulher de 69 anos que apresentou início subagudo de hemicrania à esquerda de intensidade moderada a forte sem sinais autonômicos. Oito dias após o início da cefaleia, ela apresentou paralisia facial periférica e após 4 dias, notou o aparecimento de vesículas no lado esquerdo do ouvido e dor ao engolir. Ela desenvolveu náusea com vários episódios de vômito e desequilíbrio importante que tornava a marcha impossível.

\section{Resultados}

No exame físico ela apresentou vesículas na orelha esquerda e orofaringe, paralisia facial periférica esquerda (House Brackmann grau IV), hipoacusia esquerda, nistagmo e marcha vestibular. A tomografia do cérebro e a análise do líquido cefalorraquidiano não mostraram anormalidades.

\section{Conclusões}

A infecção envolve principalmente os nervos facial e vestibulococlear, causando paralisia facial periférica, otalgia e perda auditiva. Os sintomas vestibulares são raros e o início da síndrome com cefaleia persistente, como relatado, é extremamente atípico.

Palavras-chave: Paralisia facial; Herpes-zóster, Cefaleia 